\title{
Tocilizumab in nonventilated patients hospitalized with Covid-19 pneumonia
}

Carlos Salama, MD; Jian Han, PhD; Linda Yau, MPhil, PhD; William G. Reiss, PharmD;

Benjamin Kramer, MD; Jeffrey D. Neidhart, MD; Gerard J. Criner, MD; Emma Kaplan-Lewis, MD; Rachel Baden, MD; Lavannya Pandit, MD; Miriam L. Cameron, MD; Julia Garcia-Diaz, MD; Victoria Chávez, MD; Martha Mekebeb-Reuter, MD; Ferdinando Lima Menezes, MD; Reena Shah, MScID, FRCP; Maria F. González-Lara, MD, MSc; Beverly Assman, BSc, MS; Jamie Freedman, MD, PhD; Shalini V. Mohan, MD

Elmhurst Hospital Center-Icahn School of Medicine at the Mount Sinai Hospital, Elmhurst, NY, USA (C.S.); Genentech, South San Francisco, CA, USA (J.H., L.Y., W.G.R., B.K., B.A., J.F., S.V.M.); San Juan Oncology Associates, Farmington, NM, USA (J.D.N); Lewis Katz School of Medicine at Temple University, Philadelphia, PA, USA (G.J.C.); Elmhurst Hospital Center-New York City Health and Hospitals, Elmhurst, NY, USA (E.K.-L.); Highland Hospital, Oakland, CA, USA (R.B.); Michael E. DeBakey Veterans Affairs Medical Center, Houston, TX, USA (L.P.); Holy Cross Health, Silver Spring, MD, USA (M.L.C.); Ochsner Clinic Foundation, New Orleans, LA, USA (J.G.-D.); Central Military Hospital, Lima, Peru (V.C.); Stellenbosch University, Cape Town, South Africa (M.M.-R); BR Trials - Pesquisa Clínica, Sao Paulo, SP, Brazil (F.L.M.); Aga Khan University Hospital, Nairobi, Kenya (R.S.); Instituto Nacional de Ciencias Médicas y Nutrición Salvador Zubirán, Mexico City, Mexico (M.F.G.-L.)

\section{Corresponding author:}

Shalini V. Mohan, MD

1 DNA Way

South San Francisco, CA 94080

Phone: (650) 225-1000

Email: mohan.shalini@gene.com 


\begin{abstract}
Background: Coronavirus disease 2019 (Covid-19) pneumonia is often associated with hyperinflammation. Safety and efficacy of the anti-interleukin-6 receptor antibody tocilizumab was evaluated in patients hospitalized with Covid-19 pneumonia.
\end{abstract}

Methods: Nonventilated patients hospitalized with Covid-19 pneumonia were randomized (2:1) to tocilizumab (8 mg/kg intravenous) or placebo plus standard care. Sites enrolling high-risk and minority populations were emphasized. The primary endpoint was cumulative proportion of patients requiring mechanical ventilation or who had died by Day 28.

Results: Of 389 randomized patients, 249 patients received tocilizumab and 128 received placebo in the modified intent-to-treat population (Hispanic/Latino, 56.0\%; Black/African American, 14.9\%; American Indian/Alaska Native, 12.7\%; White, 12.7\%; other/unknown, $3.7 \%)$. The cumulative proportion (95\% confidence interval $[\mathrm{CI}])$ of patients requiring mechanical ventilation or who had died by Day 28 was $12.0 \%(8.52 \%$ to $16.86 \%)$ and $19.3 \%$ ( $13.34 \%$ to $27.36 \%$ ) for the tocilizumab and placebo arms, respectively (log-rank $\mathrm{P}=0.0360$; hazard ratio, 0.56 [95\% CI, 0.33 to 0.97$]$ ). Median time to clinical failure up to Day 28 favored tocilizumab over placebo (hazard ratio 0.55 [95\% CI, 0.33 to 0.93]). All-cause mortality by Day 28 was $10.4 \%$ with tocilizumab and $8.6 \%$ with placebo (weighted difference, $2.0 \%$ [95\% CI, $5.2 \%$ to $7.8 \%$ ). In the safety population, serious adverse events occurred in $15.2 \%$ of tocilizumab patients (38/250 patients) and $19.7 \%$ of placebo patients $(25 / 127)$.

Conclusions: This trial demonstrated the efficacy and safety of tocilizumab over placebo in reducing the likelihood of progression to requiring mechanical ventilation or death in nonventilated patients hospitalized with Covid-19 pneumonia. 
medRxiv preprint doi: https://doi.org/10.1101/2020.10.21.20210203; this version posted October 23, 2020. The copyright holder for this preprint (which was not certified by peer review) is the author/funder, who has granted medRxiv a license to display the preprint in perpetuity. It is made available under a CC-BY-NC-ND 4.0 International license.

Trial registration: ClinicalTrials.gov NCT04372186 


\section{INTRODUCTION}

Coronavirus disease 2019 (Covid-19) emerged in China in December 2019 and rapidly became a public health emergency. ${ }^{1,2}$ In severe and critical cases, which occur in $14 \%$ and $5 \%$ of patients, respectively, Covid-19-associated pneumonia can lead to acute respiratory distress syndrome ${ }^{3,4}$; respiratory failure is among the leading causes of death in patients with Covid-19. ${ }^{5,6}$

Patients hospitalized with Covid-19 pneumonia often require invasive mechanical ventilation, and the mortality rate is higher in these patients, especially in those who are $>65$ years. ${ }^{7-10}$ In the absence of approved therapies for Covid-19, the mainstay of treatment for patients with Covid19 pneumonia is symptomatic and supportive, ${ }^{11}$ with dexamethasone being the only therapy demonstrated to improve patient outcomes thus far. ${ }^{12}$ A clear unmet need exists for therapies to treat Covid-19 pneumonia.,

Therapies for Covid-19 pneumonia are especially needed for underserved and racial and ethnic minority populations, who are disproportionately affected by the pandemic. ${ }^{13-21}$ In cases reported to the US Centers for Disease Control and Prevention, 33\% of patients were Hispanic and 22\% were Black, whereas these groups make up $18 \%$ and $13 \%$ of the US population, respectively. ${ }^{14}$ This is also a global issue; among 17 million patients in England, all non-White ethnic patients were found to have a higher risk of Covid-19-related death than White patients. ${ }^{15}$ Greater inclusion of minorities and underserved populations in clinical trials of Covid-19 therapies is needed; these populations are often not a focus of clinical trial recruitment and have been underrepresented in Covid-19 trials. ${ }^{22}$ Clinical data on these specific populations are urgently needed to improve patient outcomes.

Covid-19 may be associated with a dysregulated immune response and hyperinflammation, which can lead to acute respiratory distress syndrome and multiorgan failure. ${ }^{4,23,24}$ Studies have 
found that increased levels of interleukin-6 (IL-6) were associated with severe Covid-19 and increasing IL-6 levels correlated with increased likelihood of needing mechanical ventilation and mortality. ${ }^{25-27}$ The anti-IL-6 receptor monoclonal antibody tocilizumab, which is approved for multiple inflammatory diseases, ${ }^{28,29}$ has been found to improve outcomes in patients with Covid19 pneumonia in observational studies in the US and globally. ${ }^{30-34}$ Although the randomized, placebo-controlled COVACTA trial—which enrolled patients with a range of disease severity, including $38 \%$ of patients receiving mechanical ventilation-did not meet its primary endpoint, its results suggested that tocilizumab may have a positive effect on recovery time and need for intensive care, which warrants further investigation. ${ }^{35}$

The global phase III EMPACTA (Evaluating Minority Patients with Actemra) clinical trial investigated the safety and efficacy of tocilizumab in hospitalized, nonventilated patients with Covid-19 pneumonia, with an emphasis on enrolling high-risk and racial and ethnic minority populations.

\section{PATIENTS AND METHODS}

\section{Trial Design and Oversight}

EMPACTA is a randomized, double-blind, placebo-controlled, phase III study to evaluate the safety and efficacy of tocilizumab in hospitalized, nonventilated patients with Covid-19 pneumonia (ClinicalTrials.gov NCT04372186). Inclusion of global study sites enrolling highrisk and minority populations was emphasized to enhance the understanding of the clinical 
profile of tocilizumab in these patients and allow access to underserved and minority populations, which are not commonly represented in clinical trials.

Patients $\geq 18$ years of age (with no upper age limit) hospitalized with Covid-19 pneumonia confirmed by a positive polymerase chain reaction test and radiographic imaging were eligible. Patients had a blood oxygen saturation $<94 \%$ on ambient air but were excluded if they required continuous positive airway pressure, bilevel positive airway pressure, or mechanical ventilation. Patients were receiving standard care per local practice, which could include antiviral treatment, limited systemic corticosteroids ( $\leq 1 \mathrm{mg} / \mathrm{kg}$ methylprednisolone or equivalent recommended) and supportive care. Patients were excluded if progression to death was imminent and inevitable within 24 hours as determined by the treating physician or they had active tuberculosis or suspected active bacterial, fungal, or viral infection (other than SARS-CoV-2 or well-controlled HIV). Patients with comorbidities were not excluded unless the investigator determined it would preclude safe patient participation.

All patients or their legally authorized representative gave informed consent. This study was conducted in accordance with the International Council for Harmonization E6 guideline for good clinical practice and the Declaration of Helsinki or local regulations, whichever afforded greater patient protection. Institutional review boards or ethics committees approved the protocol. The sponsor (Genentech, Inc.) designed the study, conducted it per the protocol, collected the data, and performed the analyses. All authors vouch for the accuracy and completeness of the data and for the trial's fidelity to the protocol. All manuscript drafts were prepared by the authors, with editorial and writing assistance funded by the sponsor.

Patients were randomized $(2: 1)$ to intravenous tocilizumab $(8 \mathrm{mg} / \mathrm{kg}$, maximum $800 \mathrm{mg})$ or placebo, both plus standard care through permuted-block randomization and an interactive voice 
or web-based response system. Randomization was stratified by country (United States, Mexico, Kenya, South Africa, Peru, Brazil) and age ( $\leq 60$ and $>60$ years). If a patient's clinical signs or symptoms worsened or did not improve (reflected by sustained fever or worsening status on the 7-category ordinal scale), an additional infusion could be administered 8 to 24 hours after the first.

Efficacy was evaluated by Day 28, and patients were followed for a total of 60 days; patients discharged prior to Day 28 were considered study completers and followed weekly up to Day 28 with a safety follow-up by Day 60 .

\section{Outcome Measures}

The primary efficacy endpoint was cumulative proportion of patients requiring mechanical ventilation (mechanical invasive ventilation or extracorporeal membrane oxygen) or who had died by Day 28. Key secondary efficacy endpoints evaluated up to or by Day 28 were time to hospital discharge or ready for discharge based on a 7-category ordinal scale (Table S1 in the Supplementary Appendix); time to a $\geq 2$ category improvement in clinical status relative to baseline on a 7-category ordinal scale (for patients in category 2 at baseline, having a clinical status of category 1 was considered meeting the threshold); time to clinical failure (time to death, mechanical ventilation, intensive care unit [ICU] admission [or 2-category worsening in the 7category ordinal scale from baseline for patients already admitted into the ICU at study enrollment], or withdrawal [whichever occurred first]); and mortality rate. The primary efficacy endpoint was also analyzed by race/ethnicity subgroups.

Incidence and severity of adverse events, determined by the National Cancer Institute Common Terminology Criteria for Adverse Events v5.0, were evaluated. 


\section{Statistical Analysis}

A modified intent-to-treat (mITT, all randomized patients who received any study medication) population of 379 patients with 2:1 randomization was estimated to provide at least $80 \%$ power to detect a $15 \%$ difference between groups for the primary objective using a log-rank test assuming cumulative event rate (death or requiring mechanical ventilation) of $25 \%$ and $40 \%$ in the tocilizumab and placebo groups, respectively. Efficacy analyses were performed on the mITT population grouped according to randomization. Analyses were stratified by age group ( $\leq 60$ or $>60$ years).

The primary endpoint was estimated using the Kaplan-Meier method, and cumulative incidence curves were compared between treatment groups using the stratified log-rank test. The stratified Cox proportional hazard model was used to estimate the hazard ratio (tocilizumab over placebo) and $95 \%$ confidence interval (CI) between treatment arms.

Primary and key secondary endpoints were evaluated in a hierarchical manner to control the overall study-wide type 1 error rate at the 5\% significance level. If the primary endpoint reached statistical significance at the 2 -sided 5\% significance level, the key secondary endpoints were tested in the following predefined order: (1) time to hospital discharge/ready for discharge, (2) time to improvement in clinical status, (3) time to clinical failure endpoint, and (4) mortality. Time-to-event secondary endpoints were compared between treatment groups using the KaplanMeier approach. In the analyses for time to hospital discharge/ready for discharge and for time to improvement in clinical status, patients who had died or discontinued from study prior to hospital discharge/ready for discharge or prior to achieving improvement in clinical status were censored by Day 28 or date of the last ordinal scale assessment, respectively. In the analysis of the time to clinical failure endpoint, patients not experiencing clinical failure on or prior to Day 
28 were censored at the last contact date or Day 28, whichever was earlier. Mortality by Day 28 was compared between treatment arms using the Cochran-Mantel-Haenszel test adjusted for age. For subgroup analyses, see the Supplementary Appendix.

Safety was assessed in the safety evaluable population, which was all patients who received any study medication; patients were grouped by the actual treatment received.

\section{RESULTS}

\section{Patients}

Overall, 389 patients from 6 countries were randomized, with 1 patient randomized in error, and 377 received study treatment (Figure 1). In the mITT population, 249 patients received tocilizumab plus standard of care and 128 received placebo plus standard of care. The safety population included 250 and 127 patients, respectively, because 1 patient randomized to placebo received tocilizumab and 11 patients did not receive study treatment. Study drug exposure is provided in Table S2 in the Supplementary Appendix. Overall, 225 patients $(90.4 \%)$ completed the study in the tocilizumab arm and $115(89.8 \%)$ in the placebo arm; excluding those who died, no tocilizumab patients and 2 placebo patients (1.6\%) discontinued before Day 28. Median follow-up time was 10 days in both treatment arms.

Baseline demographics and disease characteristics were generally balanced between treatment arms (Table 1). In the tocilizumab and placebo arms, $60.2 \%$ and $57.0 \%$ of patients were male, respectively, and mean $( \pm \mathrm{SD})$ age was $56.0 \pm 14.3$ years and $55.6 \pm 14.9$ years, respectively. In the tocilizumab and placebo arms, 143 patients (57.4\%) and $68(53.1 \%)$ were Hispanic/Latino, respectively, 35 patients (14.1\%) and $21(16.4 \%)$ were Black/African American, respectively, 
and $33(13.3 \%)$ and $15(11.7 \%)$ were American Indian/Alaska Native, respectively. In the tocilizumab and placebo arms, use of systemic corticosteroids (200 patients [80.3\%] and 112 [87.5\%]) and antiviral treatment (196 [78.7\%] and 102 [79.7\%]) in the 7 days prior to or during the study), respectively, were similar. In the tocilizumab and placebo arms, $55.4 \%$ and $67.2 \%$ of patients received dexamethasone, respectively, and 52.6\% and 58.6\% received remdesivir, respectively.

\section{Primary Efficacy Outcome}

The primary efficacy comparison was statistically significant; the cumulative proportion of patients requiring mechanical ventilation or who had died by Day 28 was $12.0 \%$ (95\% CI, $8.52 \%$ to $16.86 \%$ ) with tocilizumab and $19.3 \%$ (95\% CI, $13.34 \%$ to $27.36 \%$ ) with placebo (hazard ratio, 0.56 [95\% CI, 0.33 to 0.97]); log-rank $\mathrm{P}=0.0360$; Table 2, Figure 2).

\section{Secondary Outcomes}

Median (95\% CI) time to hospital discharge/ready for discharge up to Day 28 was 6.0 days (6.0 to 7.0) with tocilizumab and 7.5 days (7.0 to 9.0) with placebo (hazard ratio, 1.16 [95\% CI, 0.91 to 1.48]); Table 2, Figure S1). Median (95\% CI) time to improvement in ordinal clinical status up to Day 28 was 6.0 days (6.0 to 7.0) with tocilizumab and 7.0 days (6.0 to 9.0) with placebo (hazard ratio, 1.15 [95\% CI, 0.90 to 1.48]; Table 2, Figure S2). Median (95\% CI) time to clinical failure up to Day 28 was not reached in either group (hazard ratio, 0.55 [95\% CI, 0.33 to 0.93]; Table 2, Figure S3). Mortality (95\% CI) by Day 28 was $10.4 \%$ (7.2\% to $14.9 \%$ ) in the 
tocilizumab arm and $8.6 \%(4.9 \%$ to $14.7 \%)$ in the placebo arm (weighted difference, $2 \%$ [95\% CI, $-5.2 \%$ to $7.8 \%$ )]; Table 2 ).

\section{Exploratory Outcomes}

Primary efficacy analysis results by race/ethnicity were consistent with the result for all patients (Figure S4).

\section{Safety}

Overall, adverse events were reported in $50.8 \%$ of 250 patients and $52.8 \%$ of 127 patients in the tocilizumab and placebo arms, respectively, through Day 60 (the data cutoff was September 30, 2020) and serious adverse events in $15.2 \%$ and $19.7 \%$ (Table 3). Deaths occurred in 29 patients (11.6\%) in the tocilizumab arm and $15(11.8 \%)$ in the placebo arm. Through Day 60, 13 patients receiving tocilizumab $(5.2 \%)$ had 16 serious infections and 9 patients receiving placebo $(7.1 \%)$ had 11 .

\section{DISCUSSION}

The phase III EMPACTA trial of tocilizumab in hospitalized nonventilated patients with Covid19 pneumonia emphasized enrolling high-risk and racial and ethnic minority patients, who are disproportionately affected by Covid-19 and often underrepresented in clinical trials. ${ }^{13-22}$ Overall, $>25 \%$ of patients were over age $65,>75 \%$ had $\geq 1$ comorbidity and $>80 \%$ were a racial or ethnic minority. This trial demonstrated significant reduction in the likelihood of progressing to 
mechanical ventilation or death by Day 28 in patients receiving tocilizumab plus standard care vs placebo plus standard care. When all-cause mortality alone was evaluated as a secondary endpoint, no mortality benefit was observed; however, this study was not specifically designed or powered to detect differences in mortality, making it difficult to draw conclusions based on these data. Time to clinical failure up to Day 28 favored tocilizumab over placebo.

Healthcare disparities in Covid-19 are a critical issue as studies continue to show that racial and ethnic minority populations are disproportionately affected by the pandemic. ${ }^{13-21}$ The role of race and ethnicity in Covid-19 is complex and not fully understood; social determinants of health, socioeconomic factors, and historic and structural inequities may play a role but do not completely explain the observations in the body of evidence, and further research is needed. ${ }^{16,18,21,36}$ EMPACTA directly addressed the discrepancy between the overrepresentation of racial and ethnic minorities with Covid-19 disease and their underrepresentation in Covid-19 trials $^{22}$ by prioritizing sites that provide care to underserved and minority populations while continuing to enroll all eligible patients. As a result, 84\% were either Hispanic/Latino, Black/African American, or American Indian/Alaska Native. Although the analysis was exploratory, the primary efficacy outcomes based on race were consistent with the outcome in the overall patient population.

Preventing progression to mechanical ventilation, which may greatly alter patient outcomes and healthcare resource availability, is critical for potential Covid-19 therapies. Mechanical ventilation is administered as disease severity increases and patients experience respiratory distress and failure. In an observational study of critically ill patients with Covid-19, 76\% received mechanical ventilation and the mortality rate among these patients was $35.7 \% .^{8}$ In a global literature survey of hospitalized patients with Covid-19, 63\% of those in the ICU received 
mechanical ventilation and the mortality rate for these patients was $59 \% .^{9}$ In addition to clinical decision-making, one of the main factors determining whether patients receive mechanical ventilation is availability of resources. Critical shortages of ventilators have occurred globally during the pandemic, underscoring the need for effective therapies that preserve this limited resource ${ }^{37}$; this is especially a concern in African countries. ${ }^{38}$ Reducing the proportion of patients who progress to requiring mechanical ventilation, as this study demonstrated in patients receiving tocilizumab, could help reduce the burden on critical care services, reduce direct healthcare costs, and ensure availability for the most critical patients. ${ }^{39}$

Besides EMPACTA, the efficacy of tocilizumab in Covid-19 has been examined in one other randomized placebo-controlled trial, COVACTA. ${ }^{35}$ COVACTA included patients across a spectrum of disease severity, from baseline moderate hypoxia to invasive mechanical ventilation, while EMPACTA enrolled patients who were not ventilated at baseline and who were at an earlier stage of disease. Furthermore, in contrast with COVACTA, in EMPACTA most patients received concomitant corticosteroids or antivirals, which have become the mainstay of Covid-19 standard care, ${ }^{40}$ although these treatments were not used uniformly and patients may not have received a full treatment course. Corticosteroid and antiviral use was generally balanced between arms, and EMPACTA demonstrated the added clinical benefit of tocilizumab. In COVACTA, the median time to hospital discharge was 20 and 28 days in the tocilizumab and placebo arms, respectively, whereas in EMPACTA, it was 6 and 7.5 days, respectively. ${ }^{35}$ This may reflect patients who were more severely ill or different comorbid conditions at study baseline in COVACTA, as well as improvements in the standards of care and different proportions of patients receiving concomitant steroids and antivirals. Tocilizumab was associated with a 
reduced risk of invasive mechanical ventilation or death (adjusted hazard ratio, 0.61 [95\% CI, $0.40-0.92] ; \mathrm{P}=0.020$ ) in a retrospective study. ${ }^{32}$

EMPACTA demonstrated the efficacy and safety of tocilizumab plus standard care over placebo plus standard care in reducing the likelihood of progression to requiring mechanical ventilation or death among hospitalized nonventilated patients with Covid-19 pneumonia; this is the first placebo-controlled trial to demonstrate a likelihood of reduction in progression to mechanical ventilation in Covid-19. EMPACTA is also the first trial of its kind to emphasize diversity and ensure underserved populations are represented in clinical research and given the opportunity to receive novel therapies.

\section{Acknowledgments}

We thank the patients who participated in this trial, the clinical site investigators, and Claire Stedden, Ph.D., and Nicola Gillespie, DVM, of Health Interactions for medical writing assistance with an earlier version of the manuscript. This study was funded by Genentech, Inc.

\section{Conflicts of interest}

C.S. reports personal fees from Genentech, Inc. J.H., L.Y., W.G.R., B.K., and S.V.M are employees and shareholders of Genentech, Inc. and have filed a patent for a method of treating pneumonia, including COVID-19 pneumonia, with an IL-6 antagonist. J.D.N., L.P., M.L.C., J.G.-D., V.C., M.M.-R., F.L.M., and R.S. have nothing to disclose. G.J.C. reports, outside the submitted work, grants and personal fees from Galaxo Smith Kline, Boehringer Ingelheim, 
Chiesi, Mereo, Astra Zeneca, Pulmonx, Pneumrx, Olympus, Broncus, Lungpacer, Nuvaira, ResMed, Respironics, and Patara; personal fees from Verona, BTG, EOLO, and NGM; grants from Alung, Fisher Paykel, and Galapgos. E.K.-L. reports honorarium from ViiV outside the submitted work and is a site PI for a Genentech, Inc. sponsored clinical trial. R.B. reports her institution received support from Genentech, Inc. to perform this study. M.F.G.-L. reports personal fees from Pfizer, Stendhal, and Grupo Biotoscana during the conduct of the study and personal fees from Pfizer and Stendhal outside the submitted work. B.A. and J.F. are employees and shareholders of Genentech, Inc.

\section{Data sharing statement}

Qualified researchers may request access to individual patient level data through the clinical study data request platform (https://vivli.org/). Further details on Roche's criteria for eligible studies are available here (https://vivli.org/members/ourmembers/). For further details on Roche's Global Policy on the Sharing of Clinical Information and how to request access to related clinical study documents, see here (https://www.roche.com/research and development/who we are how we work/clinical trials/ our_commitment_to_data_sharing.htm). 


\section{REFERENCES}

1. Phelan AL, Katz R, Gostin LO. The novel coronavirus originating in Wuhan, China: challenges for global health governance. JAMA 2020;323(8):709-10.

2. World Health Organization. COVID-19 Public Health Emergency of International Concern (PHEIC). 2020. (https://www.who.int/publications/m/item/covid-19-public-health-emergency-ofinternational-concern-(pheic)-global-research-and-innovation-forum).

3. $\mathrm{Wu} \mathrm{Z,} \mathrm{McGoogan} \mathrm{JM.} \mathrm{Characteristics} \mathrm{of} \mathrm{and} \mathrm{important} \mathrm{lessons} \mathrm{from} \mathrm{the} \mathrm{coronavirus} \mathrm{disease}$ 2019 (COVID-19) outbreak in China: summary of a report of $72 \square 314$ cases from the Chinese Center for Disease Control and Prevention. JAMA 2020;323(13):1239-42.

4. Chen N, Zhou M, Dong X, et al. Epidemiological and clinical characteristics of 99 cases of 2019 novel coronavirus pneumonia in Wuhan, China: a descriptive study. Lancet 2020;395(10223):507-13.

5. Gupta S, Hayek SS, Wang W, et al. Factors associated with death in critically ill patients with coronavirus disease 2019 in the US. JAMA Intern Med. DOI: 10.1001/jamainternmed.2020.3596

6. Ruan Q, Yang K, Wang W, Jiang L, Song J. Clinical predictors of mortality due to COVID-19 based on an analysis of data of 150 patients from Wuhan, China. Intensive Care Med. 2020;46(5):846-8. 7. Richardson S, Hirsch JS, Narasimhan M, et al. Presenting characteristics, comorbidities, and outcomes among 5700 patients hospitalized with COVID-19 in the New York City area. JAMA 2020;323(20):2052-9.

8. Auld SC, Caridi-Scheible M, Blum JM, et al. ICU and ventilator mortality among critically ill adults with coronavirus disease 2019. Crit Care Med 2020;48(9):e799-e804.

9. Tzotzos SJ, Fischer B, Fischer H, Zeitlinger M. Incidence of ARDS and outcomes in hospitalized patients with COVID-19: a global literature survey. Crit Care 2020;24(1):516.

10. Karagiannidis C, Mostert C, Hentschker C, et al. Case characteristics, resource use, and outcomes of $10 \square 021$ patients with COVID-19 admitted to 920 German hospitals: an observational study. Lancet Respir Med 2020;8(9):853-62. 
medRxiv preprint doi: https://doi.org/10.1101/2020.10.21.20210203; this version posted October 23, 2020. The copyright holder for this preprint (which was not certified by peer review) is the author/funder, who has granted medRxiv a license to display the preprint in perpetuity.

It is made available under a CC-BY-NC-ND 4.0 International license .

11. Fan E, Beitler JR, Brochard L, et al. COVID-19-associated acute respiratory distress syndrome: is a different approach to management warranted? Lancet Respir Med 2020;8(8):816-21.

12. Horby P, Lim WS, Emberson JR, et al. Dexamethasone in hospitalized patients with Covid-19preliminary report. N Engl J Med DOI: 10.1056/NEJMoa2021436

13. Pan D, Sze S, Minhas J, et al. The impact of ethnicity on clinical outcomes in COVID-19: a systematic review. eClinicalMedicine. 2020;23:100404.

14. Stokes EK, Zambrano LD, Anderson KN, et al. Coronavirus Disease 2019 Case Surveillance United States, January 22-May 30, 2020. MMWR Morb Mortal Wkly Rep 2020;69(24):759-65.

15. Williamson EJ, Walker AJ, Bhaskaran K, et al. OpenSAFELY: factors associated with COVID19 death in 17 million patients. Nature 2020;584(7821):430-6.

16. Egede LE, Walker RJ. Structural racism, social risk factors, and Covid-19 - a dangerous convergence for Black Americans. N Engl J Med 2020;383(12):e77

17. Karaca-Mandic P, Georgiou A, Sen S. Assessment of COVID-19 hospitalizations by race/ethnicity in 12 States. JAMA Intern Med. DOI: 10.1001/jamainternmed.2020.3857

18. Evans MK. Covid's color line - infectious disease, inequity, and racial justice. N Engl J Med 2020;383(5):408-10.

19. Price-Haywood EG, Burton J, Fort D, Seoane L. Hospitalization and mortality among black patients and white patients with Covid-19. N Engl J Med 2020;382(26):2534-43.

20. Chowkwanyun M, Reed AL. Racial health disparities and Covid-19 - caution and context. N Engl J Med 2020; 383(3):201-3.

21. Golestaneh L, Neugarten J, Fisher M, et al. The association of race and COVID-19 mortality. EClinicalMedicine 2020;25:100455.

22. Chastain DB, Osae SP, Henao-Martínez AF, Franco-Paredes C, Chastain JS, Young HN. Racial disproportionality in Covid clinical trials. N Engl J Med 2020;383(9):e59.

23. Mehta P, McAuley DF, Brown M, et al. COVID-19: consider cytokine storm syndromes and immunosuppression. Lancet 2020;395(10229):1033-4. 
24. Giamarellos-Bourboulis EJ, Netea MG, Rovina N, et al. Complex immune dysregulation in COVID-19 patients with severe respiratory failure. Cell Host Microbe 2020;27(6):992-1000.e3.

25. Aziz M, Fatima R, Assaly R. Elevated interleukin-6 and severe COVID-19: a meta-analysis. J Med Virol DOI: 10.1002/jmv.25948.

26. Zhu J, Pang J, Ji P, et al. Elevated interleukin-6 is associated with severity of COVID-19: a metaanalysis. J Med Virol. DOI: 10.1002/jmv.26085.

27. Herold T, Jurinovic V, Arnreich C, et al. Elevated levels of IL-6 and CRP predict the need for mechanical ventilation in COVID-19. J Allergy Clin Immunol 2020;146(1):128-36.e4.

28. Actemra (tocilizumab) Prescribing information. South San Francisco, CA: Genentech, Inc; 2019.

29. RoActemra (tocilizumab) Summary of product characteristics. Grenzach-Wyhlen, Germany:

Roche Registration GmbH; 2020.

30. Xu X, Han M, Li T, et al. Effective treatment of severe COVID-19 patients with tocilizumab. Proc Natl Acad Sci U S A 2020;117(20):10970-5.

31. Price CC, Altice FL, Shyr Y, et al. Tocilizumab treatment for cytokine release syndrome in hospitalized COVID-19 patients: survival and clinical outcomes. Chest. DOI:

10.1016/j.chest.2020.06.006

32. Guaraldi G, Meschiari M, Cozzi-Lepri A, et al. Tocilizumab in patients with severe COVID-19: a retrospective cohort study. Lancet Rheumatol 2020;2(8):e474-84.

33. Mastroianni A, Greco S, Apuzzo G, et al. Subcutaneous tocilizumab treatment in patients with severe COVID-19-related cytokine release syndrome: an observational cohort study. EClinicalMedicine 2020;24:100410.

34. Morrison AR, Johnson JM, Griebe KM, et al. Clinical characteristics and predictors of survival in adults with coronavirus disease 2019 receiving tocilizumab. J Autoimmun. DOI:

10.1016/j.jaut.2020.102512 
medRxiv preprint doi: https://doi.org/10.1101/2020.10.21.20210203; this version posted October 23, 2020. The copyright holder for this preprint

(which was not certified by peer review) is the author/funder, who has granted medRxiv a license to display the preprint in perpetuity.

It is made available under a CC-BY-NC-ND 4.0 International license.

35. Rosas I, Bräu N, Waters M, et al. Tocilizumab in hospitalized patients with COVID-19

pneumonia. medRxiv. DOI: 10.1101/2020.08.27.20183442

36. U.S. Department of Health and Human Services. Social determinants of health. 2020

(https://www.healthypeople.gov/2020/topics-objectives/topic/social-determinants-of-health).

37. Truog RD, Mitchell C, Daley GQ. The toughest triage - allocating ventilators in a pandemic. N Engl J Med 2020;382(21):1973-5.

38. El-Sadr WM, Justman J. Africa in the path of Covid-19. N Engl J Med 2020;383(3):e11.

39. Centers for Medicare \& Medicaid Services. COVID-19 frequently asked questions (FAQs) on

Medicare fee-for-service (FFS) billing. 2020 (https://www.cms.gov/files/document/03092020-covid-19faqs-508.pdf).

40. National Institutes of Health. Coronavirus disease 2019 (COVID-19) treatment guidelines. 2020 (https://www.covid19treatmentguidelines.nih.gov/). 


\section{TABLES AND FIGURES}

Table 1. Baseline Patient Demographics and Disease Characteristics (modified intent-to-treat population)*

\begin{tabular}{|c|c|c|c|}
\hline & $\begin{array}{c}\text { Tocilizumab } \\
\text { n=249 }\end{array}$ & $\begin{array}{c}\text { Placebo } \\
n=128\end{array}$ & $\begin{array}{l}\text { All Patients } \\
\qquad \mathbf{N}=\mathbf{3 7 7}\end{array}$ \\
\hline Sex, n (\%) & & & \\
\hline Male & $150(60.2)$ & $73(57.0)$ & $223(59.2)$ \\
\hline Female & $99(39.8)$ & $55(43.0)$ & $154(40.8)$ \\
\hline Age, mean (SD), years & $56.0(14.3)$ & $55.6(14.9)$ & $55.9(14.4)$ \\
\hline Age, median (range), years & $57.0(24-95)$ & $56.0(20-89)$ & $57.0(20-95)$ \\
\hline Age group, $\mathrm{n}(\%)$, years & & & \\
\hline $18-64$ & $178(71.5)$ & $93(72.7)$ & $271(71.9)$ \\
\hline $65-84$ & $70(28.1)$ & $33(25.8)$ & $103(27.3)$ \\
\hline$\geq 85$ & $1(0.4)$ & $2(1.6)$ & $3(0.8)$ \\
\hline Weight, mean (SD), kg & 89.57 (23.73) & $94.44(25.95)$ & $91.22(24.58)$ \\
\hline Weight, median (range), kg & $\begin{array}{c}85.00 \\
(45.4-171.8)\end{array}$ & $\begin{array}{c}90.05 \\
(44.0-201.0)\end{array}$ & $\begin{array}{c}86.00 \\
(44.0-201.0)\end{array}$ \\
\hline
\end{tabular}




\begin{tabular}{|c|c|c|c|}
\hline BMI & & & \\
\hline $\mathrm{n}$ & 240 & 122 & 362 \\
\hline BMI, mean (SD) & $32.03(7.86)$ & $33.05(7.18)$ & $32.38(7.64)$ \\
\hline BMI, median (range) & $\begin{array}{c}30.60 \\
(18.4-66.2)\end{array}$ & $\begin{array}{c}31.95 \\
(17.2-55.7)\end{array}$ & $\begin{array}{c}30.90 \\
(17.2-66.2)\end{array}$ \\
\hline Race/ethnicity, n (\%) ${ }^{\dagger}$ & & & \\
\hline Hispanic or Latino & $143(57.4)$ & $68(53.1)$ & $211(56.0)$ \\
\hline American Indian or Alaska Native & $33(13.3)$ & $15(11.7)$ & $48(12.7)$ \\
\hline Black or African American & $35(14.1)$ & $21(16.4)$ & $56(14.9)$ \\
\hline Non-Hispanic White & $28(11.2)$ & $20(15.6)$ & $48(12.7)$ \\
\hline Unknown/other & $10(4.0)$ & $4(3.1)$ & $14(3.7)$ \\
\hline Country group, $\mathrm{n}(\%)$ & & & \\
\hline US & $201(80.7)$ & $103(80.5)$ & $304(80.6)$ \\
\hline Ex-US & $48(19.3)$ & $25(19.5)$ & $73(19.4)$ \\
\hline Smoking history, $\mathrm{n}(\%)$ & & & \\
\hline Never & $192(77.1)$ & $99(77.3)$ & $291(77.2)$ \\
\hline
\end{tabular}




\begin{tabular}{|c|c|c|c|}
\hline Current & $16(6.4)$ & $6(4.7)$ & $22(5.8)$ \\
\hline Former & $41(16.5)$ & $23(18.0)$ & $64(17.0)$ \\
\hline $\begin{array}{l}\text { Ordinal scale for cl } \\
(\%)^{\S}\end{array}$ & & & \\
\hline 2 & $24(9.6)$ & $11(8.6)$ & $35(9.3)$ \\
\hline 3 & $161(64.7)$ & $81(63.3)$ & $242(64.2)$ \\
\hline 4 & $64(25.7)$ & $36(28.1)$ & $100(26.5)$ \\
\hline Elevated CRP, n (9) & & & \\
\hline $\mathrm{n}$ & 232 & 120 & 352 \\
\hline Yes & $190(81.9)$ & $104(86.7)$ & $294(83.5)$ \\
\hline No & $42(18.1)$ & $16(13.3)$ & $58(16.5)$ \\
\hline $\mathrm{CRP}, \mathrm{mg} / \mathrm{L}$ & & & \\
\hline $\mathrm{n}$ & 191 & 99 & 290 \\
\hline Mean (SD) & $151.94(177.22)$ & $202.80(404.92)$ & $169.30(277.18)$ \\
\hline Median (range) & $\begin{array}{c}123.40 \\
(2.5-2099.0)\end{array}$ & $\begin{array}{c}143.40 \\
(9.0-3776.0)\end{array}$ & $\begin{array}{c}136.05 \\
(2.5-3776.0)\end{array}$ \\
\hline
\end{tabular}




\begin{tabular}{|c|c|c|c|}
\hline hs-CRP, mg/L & & & \\
\hline $\mathrm{n}$ & 41 & 21 & 62 \\
\hline Mean (SD) & $98.23(111.36)$ & $88.46(75.01)$ & $94.92(100.00)$ \\
\hline Median (range) & $\begin{array}{c}68.25 \\
(0.1-494.7)\end{array}$ & $\begin{array}{c}76.40 \\
(2.0-290.7)\end{array}$ & $\begin{array}{c}70.85 \\
(0.1-494.7)\end{array}$ \\
\hline D-dimer, ug/mL FE & & & \\
\hline $\mathrm{n}$ & 223 & 116 & 339 \\
\hline Mean (SD) & $\begin{array}{c}423.54 \\
(1095.14)\end{array}$ & $\begin{array}{c}472.69 \\
(1392.65)\end{array}$ & $\begin{array}{c}440.36 \\
(1203.39)\end{array}$ \\
\hline Median (range) & $\begin{array}{c}1.60 \\
(0.2-8873.0)\end{array}$ & $\begin{array}{c}1.21 \\
(0.2-10384.0)\end{array}$ & $\begin{array}{c}1.55 \\
(0.2-10384.0)\end{array}$ \\
\hline Ferritin levels, pmo & & & \\
\hline $\mathrm{n}$ & 214 & 111 & 325 \\
\hline Mean (SD) & $\begin{array}{l}2305.96 \\
(3431.54)\end{array}$ & $\begin{array}{c}3585.47 \\
(12533.99)\end{array}$ & $\begin{array}{c}2742.96 \\
(7838.84)\end{array}$ \\
\hline Median (range) & $\begin{array}{c}1408.19 \\
(29.2- \\
38482.1)\end{array}$ & $\begin{array}{r}1353.14 \\
(110.1- \\
122328.9)\end{array}$ & $\begin{array}{r}1397.18 \\
(29.2- \\
122328.9)\end{array}$ \\
\hline
\end{tabular}




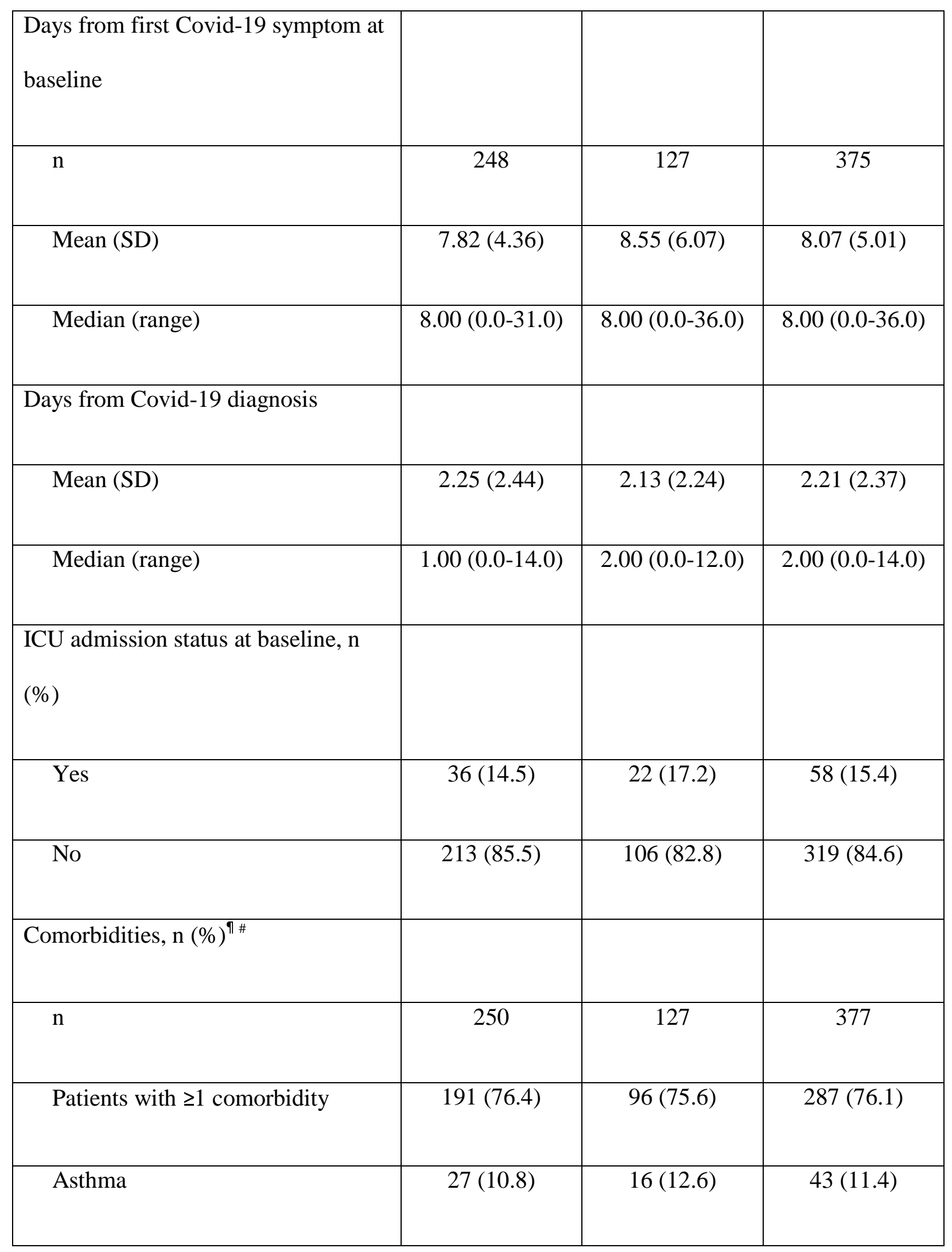




\begin{tabular}{|l|c|c|c|}
\hline Atrial fibrillation & $6(2.4)$ & $6(4.7)$ & $12(3.2)$ \\
\hline Chronic obstructive pulmonary & $12(4.8)$ & $5(3.9)$ & $17(4.5)$ \\
\hline disease & & & \\
\hline Diabetes & $105(42.0)$ & $48(37.8)$ & $153(40.6)$ \\
\hline Hyperlipidemia & $70(28.0)$ & $34(26.8)$ & $104(27.6)$ \\
\hline Hypertension & $119(47.6)$ & $63(49.6)$ & $7(48.3)$ \\
\hline Myocardial infarction & & & \\
\hline Obesity & $4(1.6)$ & $3(2.4)$ & $13(3.4)$ \\
\hline Stroke & $54(21.6)$ & $38(29.9)$ & \\
\hline & & $3(2.4)$ & \\
\hline
\end{tabular}

BMI, body mass index; CRP, C-reactive protein; FEU, fibrinogen equivalent units; hs, high sensitivity; ICU, intensive care unit.

* Unless otherwise indicated.

${ }^{\dagger}$ Self-reported.

${ }^{\ddagger}$ Mexico, Kenya, South Africa, Peru, Brazil.

${ }^{\S} 7$-category ordinal scale: 1 , discharged (or ready for discharge as evidenced by normal body temperature and respiratory rate, and stable oxygen saturation on ambient air or $\leq 2 \mathrm{~L}$

supplemental oxygen); 2, non-ICU hospital ward (or ready for hospital ward), not requiring supplemental oxygen; 3, non-ICU hospital ward (or ready for hospital ward), requiring supplemental oxygen; 4, ICU or non-ICU hospital ward, requiring noninvasive ventilation or 
medRxiv preprint doi: https://doi.org/10.1101/2020.10.21.20210203; this version posted October 23, 2020. The copyright holder for this preprint (which was not certified by peer review) is the author/funder, who has granted medRxiv a license to display the preprint in perpetuity. It is made available under a CC-BY-NC-ND 4.0 International license.

high-flow oxygen; 5, ICU, requiring intubation and mechanical ventilation; 6 , ICU, requiring extracorporeal membrane oxygenation or mechanical ventilation and additional organ support; 7 , death.

$\|_{\text {Patients with CRP }>50 \mathrm{mg} / \mathrm{L} \text { or hs-CRP }>3 \mathrm{mg} / \mathrm{L} \text { at baseline. }}$

${ }^{\mathbb{I}}$ Safety population.

${ }^{\#}$ Patients could have $>1$ condition. 
Table 2. Primary and Key Secondary Efficacy Endpoints (modified intent-to-treat population)

\begin{tabular}{|c|c|c|c|c|c|}
\hline & \multirow{2}{*}{$\begin{array}{c}\text { Tocilizumab } \\
\text { n=249 }\end{array}$} & \multirow{2}{*}{$\begin{array}{l}\text { Placebo } \\
n=128\end{array}$} & \multicolumn{3}{|c|}{ Comparison } \\
\hline & & & $\begin{array}{c}\text { Hazard } \\
\text { Ratio } \\
(95 \% \mathrm{CI})\end{array}$ & $\begin{array}{l}\text { Weighted } \\
\text { Difference, } \\
\%(95 \% \text { CI })\end{array}$ & $P$ value \\
\hline $\begin{array}{l}\text { Cumulative } \\
\text { proportion }(95 \% \mathrm{CI})^{*} \\
\text { of patients requiring } \\
\text { mechanical } \\
\text { ventilation or who } \\
\text { had died by Day } 28\end{array}$ & $\begin{array}{c}12.0 \\
(8.52-16.86)\end{array}$ & $\begin{array}{c}19.3 \\
(13.34- \\
27.36)\end{array}$ & $\begin{array}{c}0.56 \\
(0.33-0.97)\end{array}$ & - & $0.0360^{\dagger}$ \\
\hline $\begin{array}{l}\text { Time to hospital } \\
\text { discharge or ready for } \\
\text { discharge, median } \\
(95 \% \mathrm{CI}),{ }^{\ddagger} \text { days }\end{array}$ & $\begin{array}{c}6.0 \\
(6.0-7.0)\end{array}$ & $\begin{array}{c}7.5 \\
(7.0-9.0)\end{array}$ & $\begin{array}{c}1.16 \\
(0.91-1.48)\end{array}$ & - & $\S$ \\
\hline $\begin{array}{l}\text { Time to improvement } \\
\text { in ordinal clinical } \\
\text { status }{ }^{\|} \text {to Day } 28 \text {, } \\
\text { mITT population, } \\
\text { median }(95 \% \mathrm{CI}),{ }^{\ddagger} \\
\text { days }\end{array}$ & $\begin{array}{c}6.0 \\
(6.0-7.0)\end{array}$ & $\begin{array}{c}7.0 \\
(6.0-9.0)\end{array}$ & $\begin{array}{c}1.15 \\
(0.90-1.48)\end{array}$ & - & $\S$ \\
\hline
\end{tabular}




\begin{tabular}{|c|c|c|c|c|c|}
\hline $\begin{array}{l}\text { Time to clinical } \\
\text { failure, median }(95 \% \\
\mathrm{CI}),{ }^{\ddagger} \text { days }\end{array}$ & $\mathrm{NE}$ & $\mathrm{NE}$ & $\begin{array}{c}0.55 \\
(0.33-0.93)\end{array}$ & - & $\S$ \\
\hline $\begin{array}{l}\text { Mortality by Day } 28, \\
\text { n }(\%)[95 \% \mathrm{CI}]^{9 \text { \# }}\end{array}$ & $\begin{array}{l}26(10.4) \\
{[7.2-14.9]}\end{array}$ & $\begin{array}{c}11(8.6) \\
{[4.9-14.7]}\end{array}$ & - & $\begin{array}{c}2.0 \\
(-5.2-7.8)\end{array}$ & $\mathrm{s}$ \\
\hline
\end{tabular}

ICU, intensive care unit; mITT, modified intent to treat; NE, not estimable.

*Cumulative proportion of patients was estimated using the Kaplan-Meier method and compared between treatment groups using the stratified log-rank test with age group $(\leq 60,>60$ years $)$ as a stratification factor. The stratified Cox proportional hazard model with age group as a stratification factor $(\leq 60,>60$ years $)$ was used to estimate the hazard ratio and $95 \%$ CI between treatment arms.

${ }^{\dagger} \mathrm{P}$ values were calculated with the log-rank test.

Time-to-event secondary endpoints were estimated using the Kaplan-Meier approach.

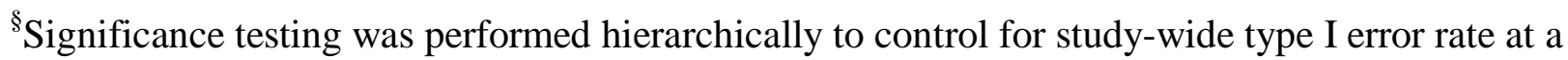
$5 \%$ significance level. Time-to-event secondary endpoints were compared between treatment groups using the Kaplan-Meier approach. P value not presented because first secondary endpoint failed to reach significance.

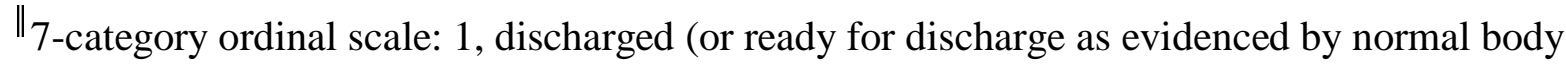
temperature and respiratory rate, and stable oxygen saturation on ambient air or $\leq 2 \mathrm{~L}$ supplemental oxygen); 2, non-ICU hospital ward (or ready for hospital ward), not requiring supplemental oxygen; 3, non-ICU hospital ward (or ready for hospital ward), requiring 
supplemental oxygen; 4, ICU or non-ICU hospital ward, requiring noninvasive ventilation or high-flow oxygen; 5, ICU, requiring intubation and mechanical ventilation; 6 , ICU, requiring extracorporeal membrane oxygenation or mechanical ventilation and additional organ support; 7 , death.

"The Wilson method was used to estimate the 95\% CI for the observed proportion. The CochranMantel-Haenszel weighting approach with age group as the stratification factor $(\leq 60,>60$ years) was used to calculate the weighted difference in percentages. The Newcombe method was used to estimate the $95 \%$ CI for the weighted difference.

${ }^{\#}$ Included all deaths reported from ordinal scale scoring, adverse events reporting and public death records, during hospital stay and after hospital discharge, through Day 28. 
Table 3. Safety Through Day 60 (safety population)

\begin{tabular}{|c|c|c|c|}
\hline & $\begin{array}{c}\text { Tocilizumab } \\
\mathbf{n}=\mathbf{2 5 0}\end{array}$ & $\begin{array}{l}\text { Placebo } \\
n=127\end{array}$ & $\begin{array}{l}\text { All Patients } \\
\qquad \mathbf{N}=\mathbf{3 7 7}\end{array}$ \\
\hline Total adverse events, $n$ & 357 & 187 & 544 \\
\hline Patients with $\geq 1$ adverse event, $\mathrm{n}(\%)$ & $127(50.8)$ & $67(52.8)$ & $194(51.5)$ \\
\hline Total deaths, $\mathrm{n}(\%)$ & $29(11.6)$ & $15(11.8)$ & $44(11.7)$ \\
\hline $\begin{array}{l}\text { Total number of patients discontinued } \\
\text { from study due to an adverse event, } n \\
(\%)\end{array}$ & 0 & 0 & 0 \\
\hline Patients with $\geq 1$ event, $\mathrm{n}(\%)$ & & & \\
\hline Adverse event with fatal outcome & $28(11.2)$ & $13(10.2)$ & $41(10.9)$ \\
\hline Serious adverse event & $38(15.2)$ & $25(19.7)$ & $63(16.7)$ \\
\hline $\begin{array}{l}\text { Serious adverse event leading to } \\
\text { withdrawal from study (excluding } \\
\text { serious adverse events leading to } \\
\text { death) }\end{array}$ & 0 & 0 & 0 \\
\hline $\begin{array}{l}\text { Serious adverse event leading to } \\
\text { dose modification or interruption }\end{array}$ & 0 & 0 & 0 \\
\hline
\end{tabular}




\begin{tabular}{|c|c|c|c|}
\hline $\begin{array}{l}\text { Treatment-related } * \text { serious adverse } \\
\text { event }\end{array}$ & $3(1.2)$ & 0 & $3(0.8)$ \\
\hline $\begin{array}{l}\text { Adverse event leading to } \\
\text { withdrawal from study (excluding } \\
\text { adverse events leading to death) }\end{array}$ & 0 & 0 & 0 \\
\hline $\begin{array}{l}\text { Adverse event leading to dose } \\
\text { modification or interruption }\end{array}$ & $1(0.4)$ & 0 & $1(0.3)$ \\
\hline Treatment-related $*$ adverse event & $32(12.8)$ & $5(3.9)$ & $37(9.8)$ \\
\hline $\begin{array}{l}\text { Treatment-related* adverse event } \\
\text { leading to withdrawal from } \\
\text { treatment }\end{array}$ & 0 & 0 & 0 \\
\hline $\begin{array}{l}\text { Treatment-related* adverse event } \\
\text { leading to dose modification or } \\
\text { interruption }\end{array}$ & 0 & 0 & 0 \\
\hline $\begin{array}{l}\text { Grades } 3 \text { to } 5 \text { adverse event (at } \\
\text { greatest intensity) }^{\dagger}\end{array}$ & $46(18.4)$ & $31(24.4)$ & $77(20.4)$ \\
\hline Infection adverse event & $25(10.0)$ & $16(12.6)$ & $41(10.9)$ \\
\hline Serious infection adverse event & $13(5.2)$ & $9(7.1)$ & $22(5.8)$ \\
\hline
\end{tabular}


medRxiv preprint doi: https://doi.org/10.1101/2020.10.21.20210203; this version posted October 23, 2020. The copyright holder for this preprint (which was not certified by peer review) is the author/funder, who has granted medRxiv a license to display the preprint in perpetuity. It is made available under a CC-BY-NC-ND 4.0 International license .

\begin{tabular}{|c|c|c|c|}
\hline $\begin{array}{c}\text { Total number of events } \\
\text { Events with incidence of }>1 \%\end{array}$ & 16 & 11 & \\
\hline in either treatment arm & & $3(2.4)$ & $8(2.1)$ \\
\hline Septic shock & $5(2.0)$ & $3(2.4)$ & $5(1.3)$ \\
\hline Covid-19 pneumonia & $2(0.8)$ & $3(2.4)$ & $3(0.8)$ \\
\hline Pneumonia & 0 & & $2(0.5)$ \\
\hline Pneumonia bacterial & 0 & & \\
\hline
\end{tabular}

*As determined by the investigator.

${ }^{\dagger}$ Incidence and severity of adverse events as determined by the National Cancer Institute Common Terminology Criteria for Adverse Events v5.0, were evaluated. 
Figure 1. Patient Disposition

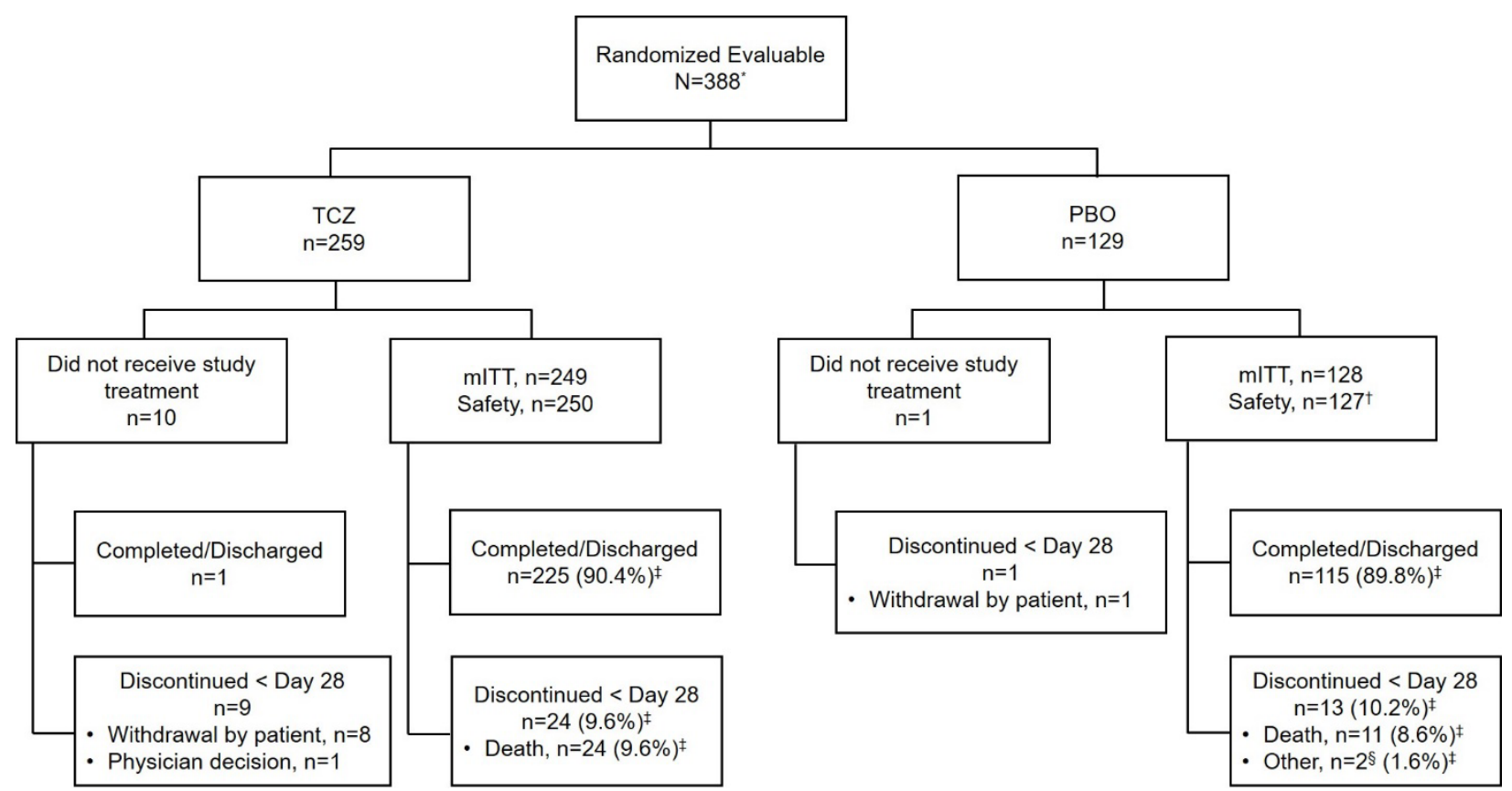

mITT, modified intent to treat, which included all randomized patients who received study treatment; PBO, placebo; TCZ, tocilizumab.

*A total of 389 patients were randomized; 1 patient was randomized prior to local institutional review board approval of study site. This patient did not receive study drug, and no further data were collected for this patient, resulting in 388 evaluable patients.

${ }^{\dagger}$ One patient randomized to the placebo group received tocilizumab and was included in the tocilizumab group in the safety population.

${ }^{\ddagger}$ Percentages based on mITT population.

${ }^{\S}$ Patients were transferred to other facilities. 
medRxiv preprint doi: https://doi.org/10.1101/2020.10.21.20210203; this version posted October 23, 2020. The copyright holder for this preprint (which was not certified by peer review) is the author/funder, who has granted medRxiv a license to display the preprint in perpetuity.

It is made available under a CC-BY-NC-ND 4.0 International license .

Figure 2. Cumulative Proportion Plot of Time to Requiring Mechanical Ventilation or Death by Day 28 (modified-intent-to-treat population)*

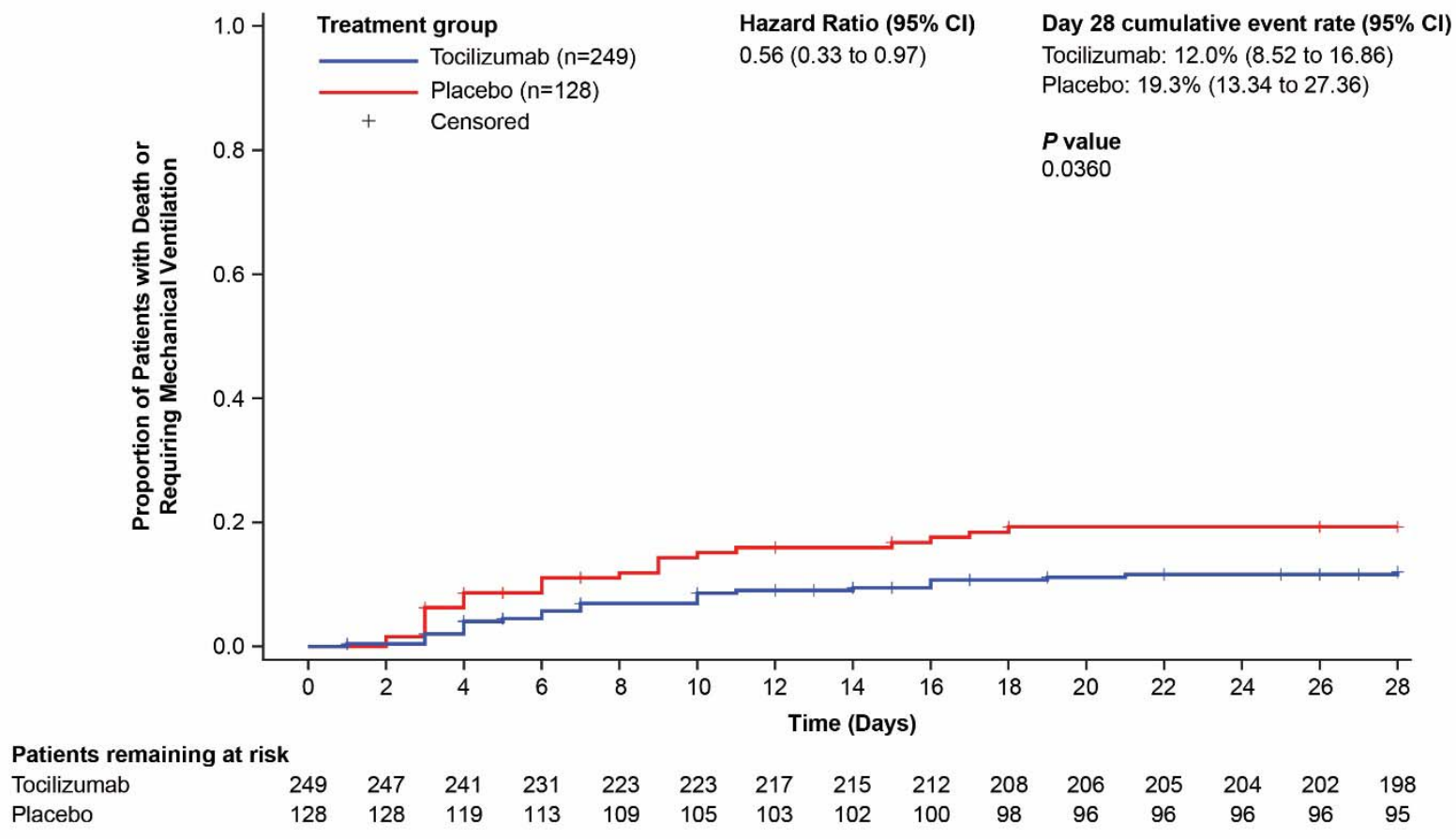

*The cumulative proportion of patients was estimated using the Kaplan-Meier method and compared between treatment groups using the stratified log-rank test. The stratified Cox proportional hazard model was used to estimate the hazard ratio and $95 \%$ confidence interval (CI) between treatment arms. 